\title{
Suspected toxicopathic hepatic necrosis and megalocytosis in pen-reared Atlantic salmon Salmo salar in Puget Sound, Washington, USA
}

\author{
Michael L. Kent ${ }^{1}$, M. S. Myers ${ }^{2}$, D. E. Hinton ${ }^{3}$, W. D. Eaton ${ }^{4}$, R. A. Elston ${ }^{1}$ \\ ${ }^{1}$ Battelle Marine Research Laboratory, 439 West Sequim Bay Rd, Sequim, Washington 98382, USA \\ ${ }^{2}$ Environmental Conservation Division, National Marine Fisheries Service, 2725 Montlake Blvd East, Seattle, Washington \\ 98112 , USA \\ ${ }^{3}$ Department of Medicine, School of Veterinary Medicine, University of California, Davis, California 95616, USA \\ ${ }^{4}$ School of Fisheries and Science, University of Alaska-Southeast, Juneau, Alaska 99801, USA
}

\begin{abstract}
Severe liver disease was associated with mortality in Atlantic salmon Salmo salar maintained in seawater net pens in Port Townsend Bay, Washington, USA. Approximately 2 mo after seawater introduction prominent diffuse hydropic degeneration and pyknosis of hepatocytes were observed in moribund fish. As the disease progressed, the livers of affected fish exhibited multifocal areas of regenerating hepatocytes intermixed throughout a necrotic parenchyma. Nuclear pleomorphism, karyomegaly and hepatic megalocytosis were prominent in fish surviving at 6 mo post seawater introduction, and many of the enlarged hepatocytes exhibited nuclear inclusions which arose from cytoplasmic invaginations. The lesions were consistent with toxicopathic changes; bacterial and viral examinations revealed no infectious agent associated with the liver damage. The source of the suspected toxicant was most likely direct water contact or natural food rather than the commercial feed because the liver lesions were not detected in Atlantic salmon fed the same commercial diet but reared at a different seawater location (Port Angeles, Washington). Furthermore, fish at both locations originated from the same freshwater hatchery and were of the same genetic strains. Cumulative mortalities at the Port Townsend sites were over $90 \%$, attributed primarily to the liver lesions. However, some moribund fish also had idiopathic pancreatitis; Aeromonas salmonicida, Cytophaga-Flexibacter and sea lice Lepeophtheirus salmonis infections; others were lost to seal predation.
\end{abstract}

\section{INTRODUCTION}

Liver lesions, including neoplasms, in numerous species of feral fishes from coastal waters throughout the world have been associated with xenobiotic contaminants (Mix 1986). This association is well documented in flatfishes from Puget Sound, Washington, USA (Malins et al. 1984, 1985a, b, Krahn et al. 1986). Myers et al. (1987) reported specific associations among various co-occurring degenerative, regenerative, preneoplastic and neoplastic hepatic lesions in English sole Parophrys vetulus. These studies involved wild fishes - we know of no studies which describe liver disease in captive fishes maintained in polluted coastal waterways.

Aquaculture of Atlantic salmon Salmo salar in seawater net pens is a large industry in Europe and is rapidly growing in Puget Sound and other coastal areas of North America. Fish in net pens are subject to waterborne toxicants, and their diseases may therefore serve as indication of anthropogenic contamination. In contrast to wild fish sentinels for environmental pollution, the genetic and nutritional history and age are usually available for cultured fishes. The progression of pathological changes can thus be more precisely followed. We report here on the sequential occurrence of several toxicopathic liver lesions which were subsequently fatal in Atlantic salmon following introduction of the fish to seawater net pens in Port Townsend Bay, Puget Sound.

\section{MATERIAL AND METHODS}

Atlantic salmon Salmo salar maintained in net pens at 2 sites (Fig. 1) in Port Townsend Bay, Puget Sound, 

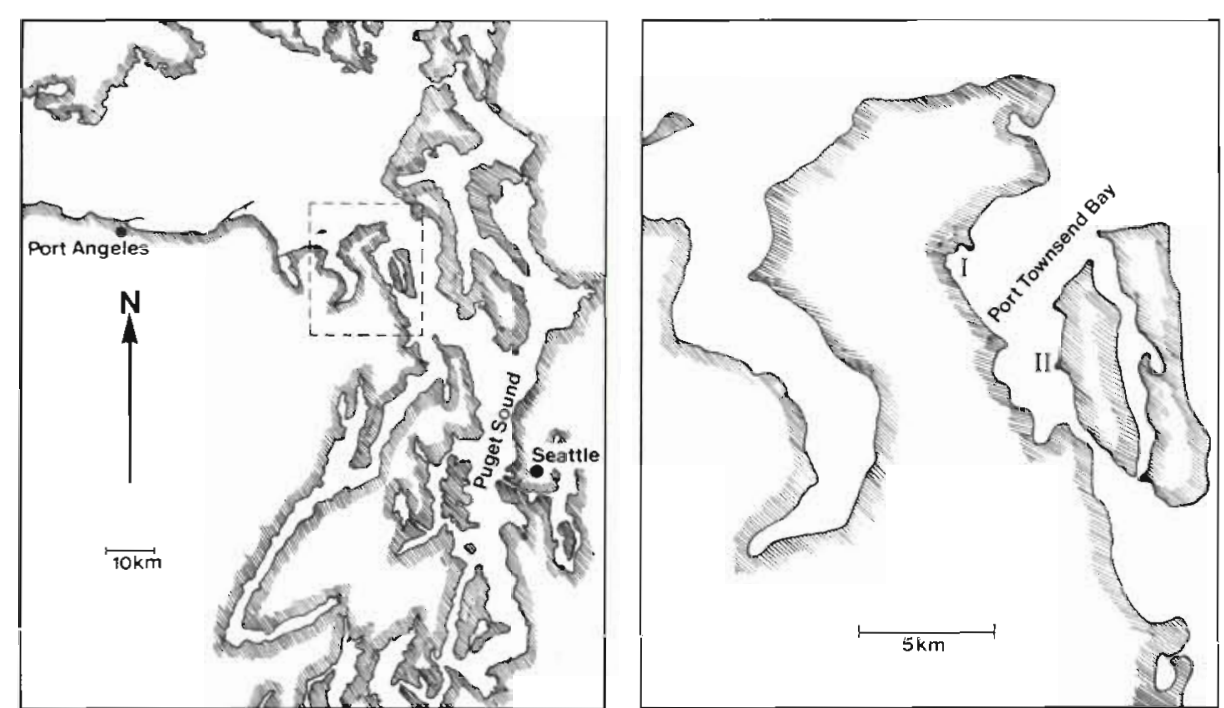

Fig. 1. Location of Atlantic salmon Salmo salar net pen sites (I and II) in Port Townsend Bay, Washington, USA
Washington, USA, were examined on the dates indicated in Table 1. All fish were moribund unless otherwise indicated. The fish were fed a standard commercial diet throughout the study. Mortality data were recorded by hatchery personnel at each site. Livers from Atlantic salmon from an unaffected site in Port Angeles, Washington (Fig. 1) were also examined and served as controls (Fig. 2).

Histology. Gills and visceral organs fixed in Davidson's solution (Humason 1979) were processed for histological examination, using standard techniques. Slides were stained with Harris' hematoxylin and eosin, Perl's stain for iron, acid-fast and periodic acidSchiff's (PAS) as described by Luna (1968). Liver tissue for electron microscopy was fixed in $3 \%$ glutaraldehyde in a cacodylate buffer using standard techniques as described by Harrell et al. (1986).

Bacteriology and virology. Bacterial examinations were performed on the fish collected on 19 August and 19 September 1986 from Site I and on fish transferred to the Battelle Marine Research Laboratory, Sequim, Washington in March 1987. Aseptic kidney and liver inocula were streaked on sheep's blood agar and Marine Agar (Difco) plates and cultured at $15^{\circ} \mathrm{C}$ and at room temperature. An examination for virus infection was conducted on the samples collected on 28 February and 6 March 1987. Liver, pancreas, kidney and spleen tissues were inoculated on CHSE-214, RTG-2, and EPC cell lines and on an Atlantic salmon cell line (AS), using standard procedures (Amos 1985). Cultures were incubated at 10 and $15^{\circ} \mathrm{C}$ and cultures that did not exhibit cytopathological effects (CPE) were blindpassed after $21 \mathrm{~d}$. Cultures were examined for CPE for an additional $21 \mathrm{~d}$ after passage.

Transmission. To further elucidate the role of a possible infectious agent (i.e. virus) in the disease, 10 unaffected Atlantic salmon from a freshwater hatchery were acclimated to seawater at the Battelle Marine Research Laboratory, Sequim, Washington and exposed to tissue homogenates of livers with megalocytosis and nuclear inclusions taken from salmon at Site II by the following method. Liver and spleen tissues from 3 affected fish from the March 1987 sample were homogenized with equal parts Minimal Essential Medium, filtered at $0.4 \mu \mathrm{m}$, and $0.25 \mathrm{ml}$ of the solution was injected into the peritoneal cavity of each of the unaffected fish. These and 10 control fish were maintained on running seawater at $11^{\circ} \mathrm{C}$ and examined histologically $45 \mathrm{~d}$ after injection.

\section{RESULTS}

\section{Husbandry and mortality history}

On 17 June 1986, 1040 Atlantic salmon smolts were introduced to seawater net pens at Site $\mathrm{I}$; and on 31 July 1986, 9228 smolts were introduced to Site II at Port Townsend Bay (Fig. 1). The fish were approximately 18 mo old at the time of introduction. Unusual mortalities were observed first at Site I in August 1986 and at Site II in September 1986, and mortalities continued at both sites until the study was terminated (Table 1). On 5 December 1986 the surviving 82 fish (8\%) at Site I were transferred to Site II. Fish with similar clinical signs continued to die through the winter, but predation by seals contributed to the overall mortality at this time. By 13 March 1987, only $4.6 \%$ of the original stock was alive at Site II. At this time, 30 fish were transferred to the Battelle Marine Research Laboratory to be maintained in seawater aquaria, and the remaining survivors at Site II were destroyed. 
Table 1. Salmo salar. Prevalence of hepatic lesions in Atlantic salmon reared at 2 seawater net pen sites in Port Townsend Bay, Puget Sound, Washington, USA

\begin{tabular}{|c|c|c|c|c|c|c|c|c|}
\hline Type of lesion & $\begin{array}{l}\text { 19 Aug } 86 \\
63 \mathrm{~d} \mathrm{PI} \\
\text { Site I }\end{array}$ & $\begin{array}{l}19 \text { Sep } 86 \\
94 \mathrm{~d} \text { PI } \\
\text { Site I }\end{array}$ & $\begin{array}{l}19 \text { Sep } 86 \\
50 \text { d PI } \\
\text { Site II }\end{array}$ & $\begin{array}{l}19 \text { Oct } 86 \\
80 \mathrm{~d} \text { PI } \\
\text { Site II }\end{array}$ & $\begin{array}{l}2 \text { Feb } 87 \\
186 \mathrm{~d} \text { PI } \\
\text { Site II }\end{array}$ & $\begin{array}{l}28 \text { Feb } 87 \\
212 \mathrm{~d} \mathrm{PI}^{\mathrm{P}} \\
\text { Site II }\end{array}$ & $\begin{array}{l}28 \text { Feb } 87 \\
212 \mathrm{dPI} \\
\text { Site II }\end{array}$ & $\begin{array}{l}6 \text { Mar } 87 \\
219 \text { d PI } \\
\text { Site II }\end{array}$ \\
\hline Diffuse hepatic necrosis & $12 / 15^{d}$ & $2 / 5$ & $3 / 4$ & $4 / 5$ & $1 / 20$ & $6 / 10$ & $2 / 10$ & $0 / 10$ \\
\hline Diffuse hydropic degeneration & $10 / 15$ & $2 / 5$ & $2 / 4$ & $1 / 5$ & $1 / 20$ & $0 / 10$ & $0 / 10$ & $0 / 10$ \\
\hline Regenerative islands & $8 / 15$ & $3 / 5$ & $2 / 4$ & $2 / 5$ & $1 / 20$ & $1 / 10$ & $1 / 10$ & $0 / 10$ \\
\hline Focal inflammation & $0 / 15$ & $0 / 5$ & $0 / 4$ & $0 / 5$ & $15 / 20$ & $2 / 10$ & $4 / 10$ & $9 / 10$ \\
\hline $\begin{array}{l}\text { Megalocytosis/nuclear } \\
\text { pleomorphism of hepatocytes }\end{array}$ & $11 / 15$ & $3 / 5$ & $2 / 4$ & $5 / 5$ & $10 / 20$ & $10 / 10$ & $10 / 10$ & $9 / 10$ \\
\hline Nuclear inclusions in hepatocytes & $1 / 15$ & $0 / 5$ & $0 / 4$ & $1 / 5$ & $5 / 20$ & $9 / 10$ & $4 / 10$ & $4 / 10$ \\
\hline Normal livers & $0 / 15$ & $1 / 5$ & $1 / 4$ & $0 / 5$ & $1 / 20$ & $0 / 10$ & $0 / 10$ & $1 / 10$ \\
\hline $\begin{array}{l}\text { Exocrine pancreas atrophy and } \\
\text { necrosis }\end{array}$ & $0 / 15$ & $1 / 5$ & $2 / 4$ & $0 / 5$ & $0 / 20$ & $0 / 10$ & $0 / 10$ & $0 / 10$ \\
\hline Cumulative mortality $(\%)$ & 70 & 79 & 39 & 51 & NA & NA & NA & 95 \\
\hline \multicolumn{9}{|c|}{$\begin{array}{l}\text { a Days post introduction to net pens } \\
\text { b Moribund fish; }{ }^{c} \text { apparently healthy fish } \\
\text { d Number with lesion/number examined } \\
\text { NA: no mortality data available }\end{array}$} \\
\hline
\end{tabular}

Fish examined at the Port Angeles site (control fish) were introduced to seawater in the spring of 1986 . This site was managed by the same company as the Port Townsend sites, and husbandry practices were essentially identical at all 3 sites. These fish did not exhibit unusual mortality through 1986.

\section{Gross pathology}

Fish from the Port Townsend sites exhibited similar clinical signs and gross pathological changes at each necropsy date indicated in Table 1 ; typically, they were dark-colored, emaciated and lethargic. Internal examination revealed the most striking changes in the liver, which often appeared pale and mottled. Severe histological lesions were associated with atrophied, unusually opaque and yellow-orange livers. Five of 8 fish examined in September 1986 exhibited erosion of the jaw associated with massive accumulations of Cytophaga-Flexibacter-like bacteria. All fish examined on 2 February 1987 exhibited moderate petechial hemorrhaging in the skin on the ventral aspect associated with infections by sea lice Lepeophtheirus salmonis (Copepoda).

Approximately 250 first year smolts from the Port Angeles site were necropsied on 31 separate dates throughout 1986 . These fish were affected with various diseases including bacterial kidney disease, Cytophaga-Flexibacter infections, sea lice infestations, and idiopathic pancreatitis; however none exhibited the yellow or atrophied livers as observed in the Port Townsend fish.

\section{Histology}

The livers of the Port Townsend fish were the only organs which showed consistent histopathological changes at all necropsies (Table 1). In the August 1986 sample, prominent, diffuse, hydropic degeneration of hepatocytes was seen (Fig. 3). Among the vacuolated cells were frankly necrotic hepatocytes with pyknotic nuclei and regenerative islands composed of small, basophilic hepatocytes. Some necrotic hepatocytes exhibited nuclear pleomorphism; some nuclei were extremely enlarged and hyperchromatic, with concomitant hepatocellular hypertrophy (megalocytosis). However, the latter condition was difficult to ascertain when the hepatocytes were extremely degenerate.

As in August, the most significant pathological changes in fish from both sites in September 1986 were in the liver (Table 1). Again, prominent, diffuse, hydropic hepatocellular degeneration was seen in the livers. Pyknosis of hepatocytes was diffuse, and hepatic tissue with severe necrosis often exhibited prominent perivascular cuffing by inflammatory cells (Fig. 4). In addition to liver lesions, all fish exhibited prominent melanization of the kidney interstitium (Fig. 5). Some fish from both sites also exhibited mild, diffuse atrophy and necrosis of the exocrine pancreas (Table 1).

Moribund fish from Site II, examined in October 1986, also showed hepatic necrosis (Table 1). Affected hepatocytes were hypertrophied, had undergone eosinophilic change and, as observed previously, exhibited prominent hydropic degeneration. Intermixed throughout the affected parenchyma were large areas of regenerative hepatocytes (Fig. 6). In one fish hepatic 

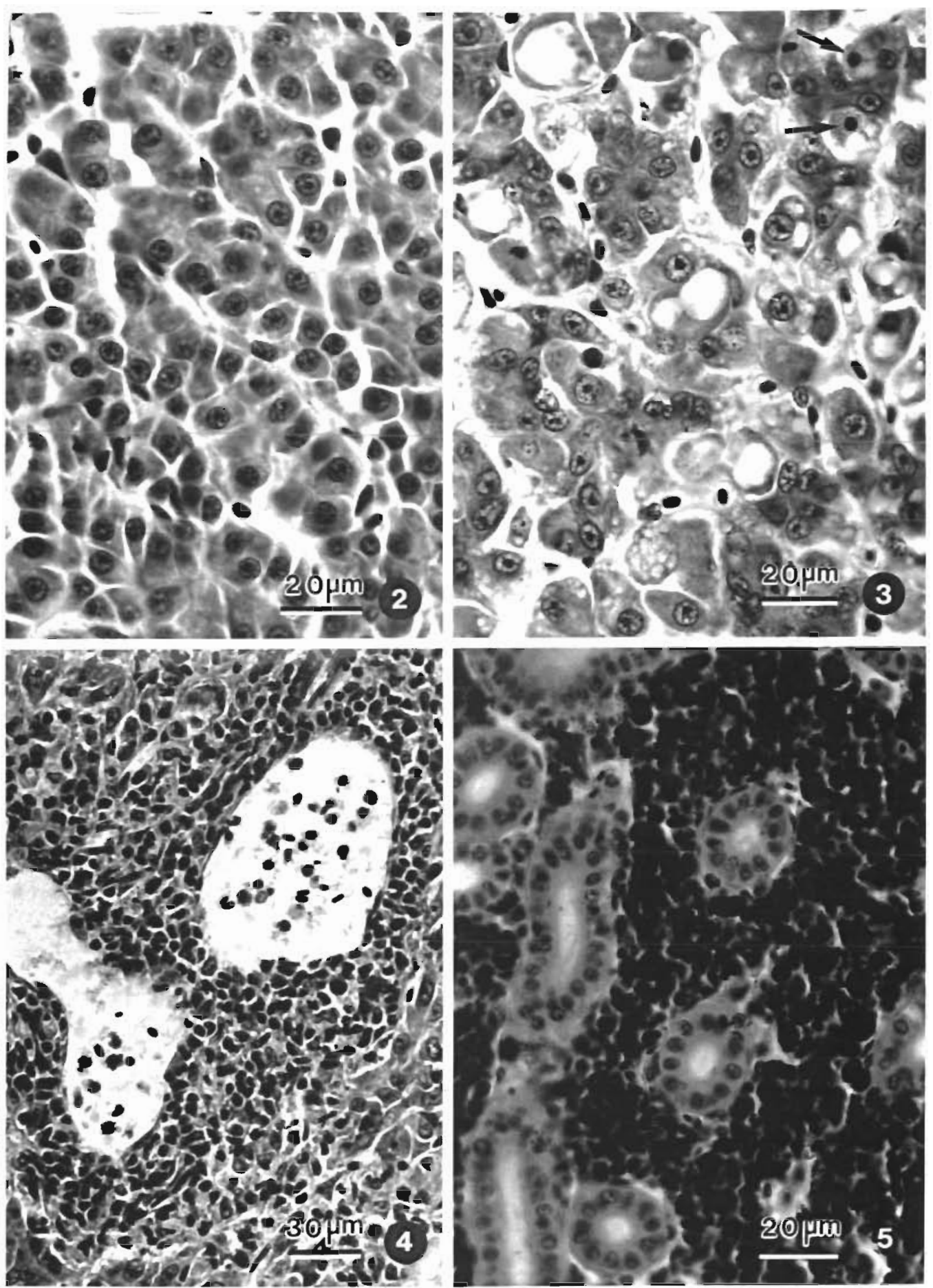

Figs. 2 to 5. Salmo salar. Normal liver of an Atlantic salmon in seawater from an unaffected site, and liver and kidney of Atlantic salmon reared in net pens from Port Townsend Bay. H\& E. Fig. 2. Normal liver; well-organized hepatic tubules, lack of vacuolation of the hepatocytes and homogeneous size of hepatocyte nuclei. Fig. 3. Diffuse hydropic (vacuolar) degeneration and necrosis in the liver 2 mo after introduction to seawater. Arrows: pyknotic nuclei. Fig. 4. Perivascular cuffing in liver with diffuse necrosis. Ficy. 5. Melanin deposition in the kidney interstitium of a fish with hepatic necrosis 


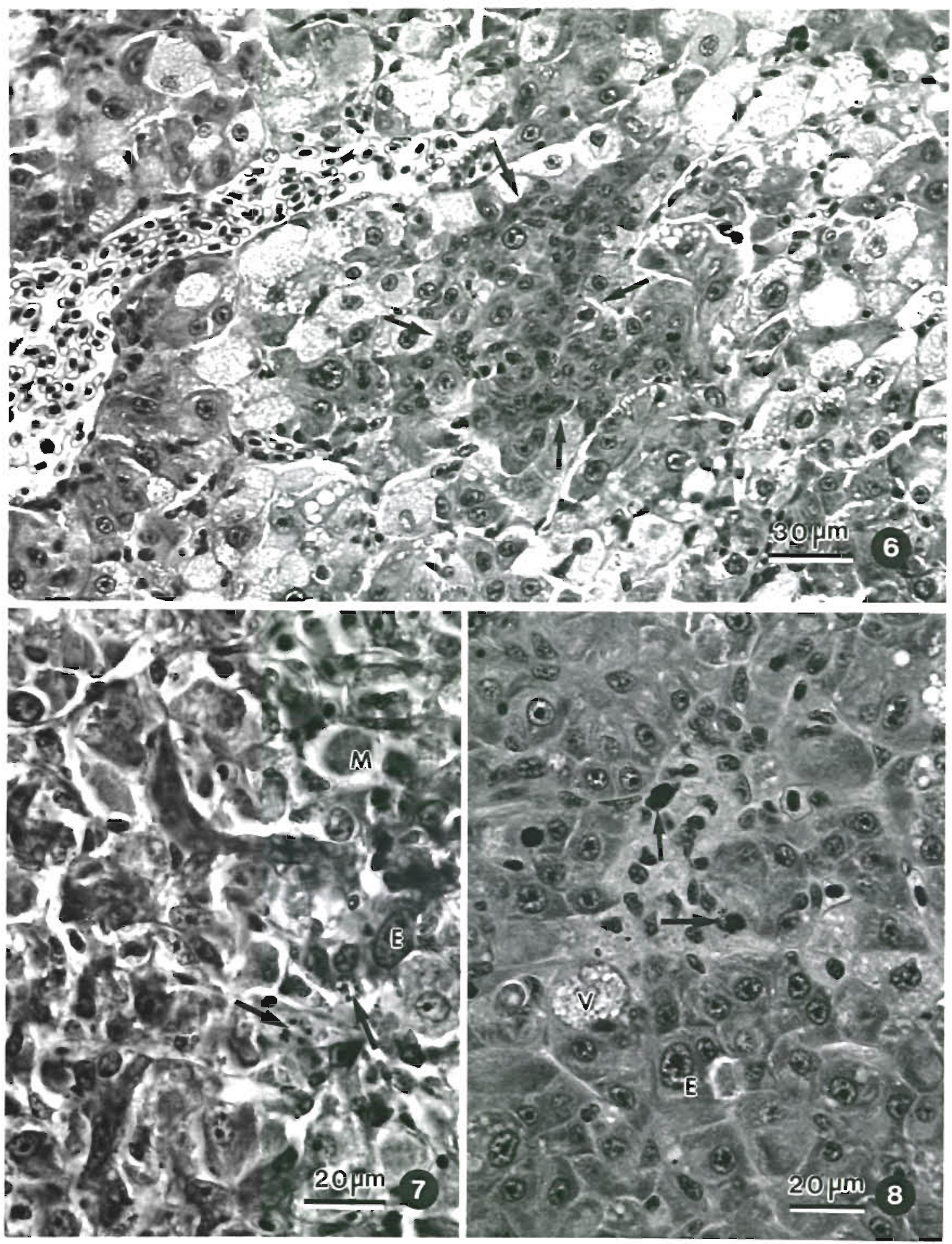

Figs. 6 to 8. Salmo salar. Livers of Atlantic salmon reared in Port Townsend Bay. H \& E. Fig. 6. Regenerative island of hepatocytes (arrows) within a liver with diffuse hydropic degeneration. Fig. 7. Severe diffuse necrosis. Note karyorrhectic nuclei (arrows), enlarged nuclei (E) and macrophages laden with ceroid/lipofuscin (M). Fig. 8. Focal inflammation of the liver with melanomacrophages (arrows). Note enlarged hepatocyte nuclei (E) and vacuolation of individual hepatocytes (V) 
necrosis was so severe and diffuse that no normal hepatocytes were identifiable (Fig. 7). Present throughout this liver, and to a lesser extent in less severely affected fish, were numerous macrophages laden with hemosiderin and ceroid as identified by Perl's stain for iron, PAS and acid-fast stains. As in the previous month, some fish exhibited diffuse necrosis and atrophy of the exocrine pancreas and associated visceral fat.

By February 1987, overall liver morphology had improved and necrosis was less severe. Fish from the February and March 1987 samples had similar lesions. Multifocal areas of mononuclear inflammatory cells, including melano-macrophages, were consistently observed in the liver parenchyma of most fish, and hydropic degeneration of hepatocytes was usualiy limited to individual cells (Fig. 8). Nuclear pleomorphism and megalocytosis were prominent at this time, and some hepatocytes were multinucleated (Fig. 9); many also exhibited nuclear bodies. The inclusions were eosinophilic, with basophilic margins; they were Feulgen-negative and measured up to $20 \mu \mathrm{m}$ in diameter (Fig. 9). Electron microscopy revealed that the inclusions were, in fact, invaginations of cytoplasmic material; they were bound by the nuclear membrane, were often visually continuous with the cytoplasm and contained abundant rough endoplasmic reticulum (Fig. 10). Severely affected livers exhibited a pronounced alteration of liver architecture; hepatocytes were in a chaotic arrangement, well-defined hepatic tubules were often absent and mitotic figures were abundant (Fig. 9). These changes, as well as diffuse necrosis and perivascular cuffing, were more severe and more prevalent in moribund fish (Table 1).

The survivors from Site II that were transferred to the Battelle laboratory in March 1987 all died by July 1987 However, histological examination of 15 of these fish indicated that they were recovering from the liver disease $_{i}$ hydropic degeneration and pyknosis of hepatocytes was absent and few hepatocytes exhibited enlarged nuclei. These fish most likely died from chronic Aeromonas salmonicida infections and most livers revealed colonies of short bacilli, which is consistent with this bacterial disease.

Histological examinations were conducted on fish from 22 of the 31 Port Angeles necropsy cases, resulting in histological examination of livers and other visceral tissues flon a total of 218 individual fish. Many of these fish exhibited histological changes consistent with bacterial kidney disease or idiopathic pancreatitis but none exhibited changes in the liver (Fig. 2) as described in the Port Townsend fish.

\section{Bacteriology and virology}

No pathogenic bacteria were isolated from the kidneys or livers of pen-reared fish with liver lesions that were examined in August and September 1986. Aeromonas salmonicida was isolated from moribund fish at the Battelle laboratory in March 1987. Attempts at isolation of viruses from affected fish revealed no cytopathological effects on the cell lines employed. Furthermore, extensive electron microscopy of livers
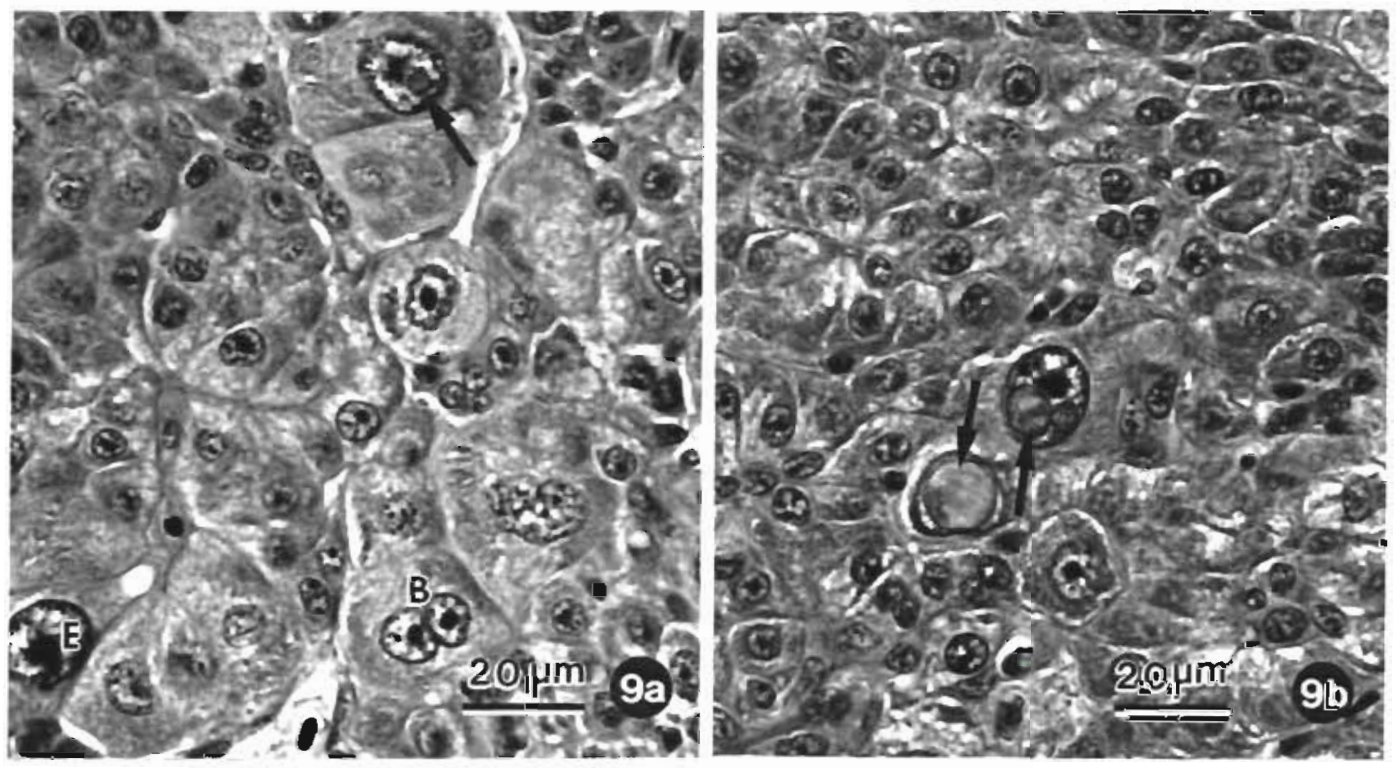

Fig. 9. Salmo salar. (a, b) Prominent megalocytosis in the liver of Atlantic salmon 6 mo after introduction to seawater in Port Townsend Bay. Note enlarged nuclei with inclusions (arrows), binucleate hepatocyte (B) and loss of liver architecture. H \& E 


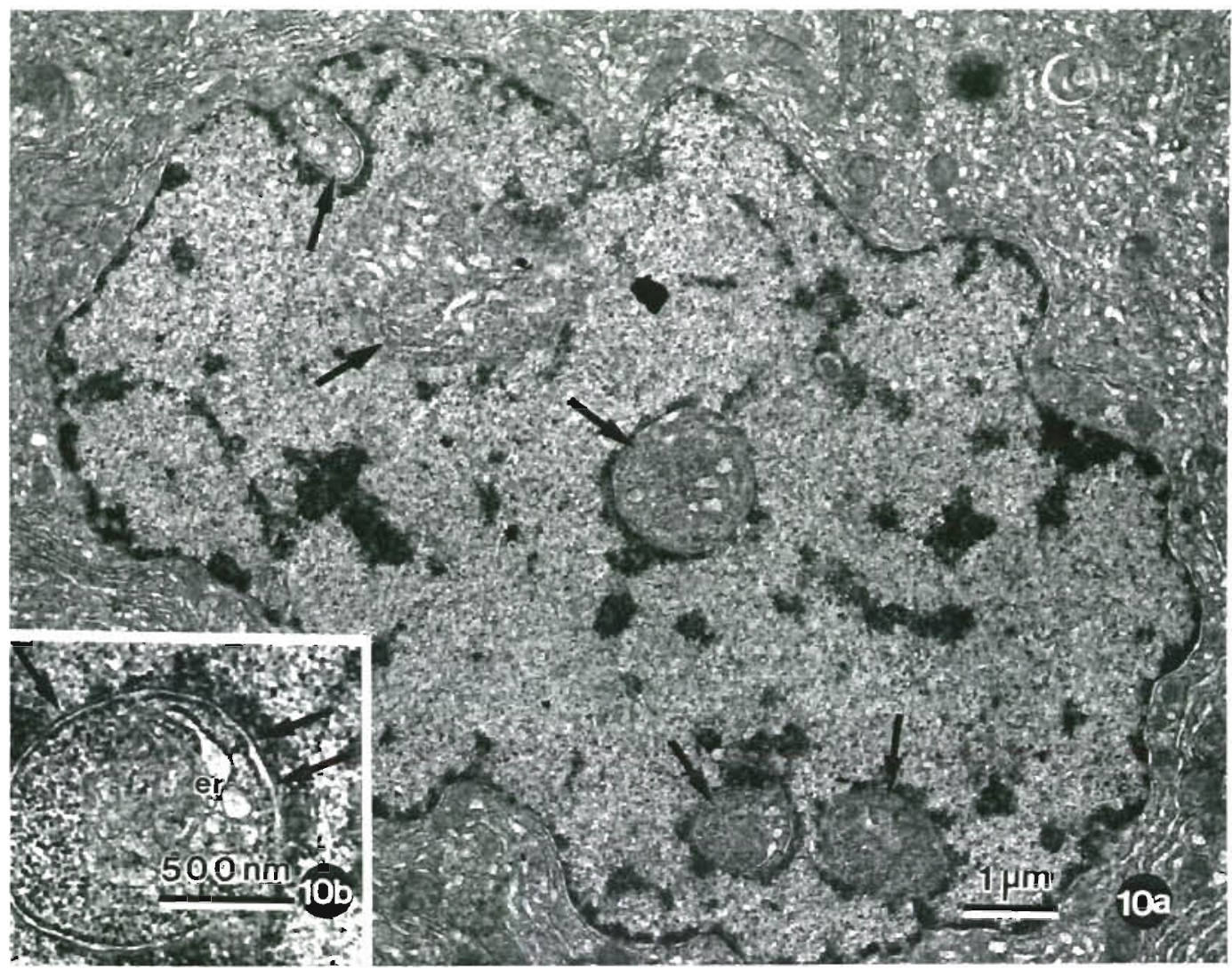

Fig. 10. Salmo salar. Electron micrograph of an enlarged hepatocyte nucleus from an Atlantic salmon with megalocytosis. (a) Note inclusion bodies (arrows) arising from cytoplasmic invaginations. (b) High magnification of inclusion with endoplasmic reticulum (ER) and bound by the nuclear membrane (arrows)

from the 2 February 1987 collections revealed no virus particles.

\section{Transmission}

Neither the 10 fish which were injected with affected liver tissue nor the controls exhibited pathological changes in the liver at $45 \mathrm{~d}$ after injection.

\section{DISCUSSION}

The liver lesions reported here were likely the primary cause of the severe mortalities observed at the 2 net-pen sites in Port Townsend Bay and were the most consistent and remarkable feature in moribund fish. Evidence indicates that the lesions were induced by a water-borne toxicant, but it was not determined if the cause was a naturally occurring toxin or an anthropogenic contaminant. The precise percentage of mortalities caused directly by the liver disease was not determined because sea lice and bacterial infections, predation by seals and pancreatic lesions were also observed. The time of onset and histological characteristics of the lesions in the exocrine pancreas are consistent with 'idiopathic pancreatitis'. This is a common disease of Atlantic salmon but it has not previously been associated with liver lesions (Munro et al. 1984, Ferguson et al. 1986, Kent \& Elston 1987).

The fish at the Port Townsend sites were part of a commercial production operation and, therefore, the study was not initiated until the fish first exhibited unusual mortality, which was 2 mo after seawater introduction at both sites, and samples prior to the onset of morbidity were not available. However, using subsequent periodic sampling for the next several months, a progression of the liver lesions was followed from onset of clinical disease through eventual death of essentially all the fish (Table 1). The initial lesion was diffuse cytoplasmic vacuolation or hydropic degeneration of the hepatocytes, with minimal nuclear degeneration. In some fish species, vacuolation of hepatocytes often indicates fat or glycogen accumulation and is not associated with disease. However, vacuolation is apparently the first pathological change in the liver disease described here because examination of hundreds of 
apparently normal livers from the Atlantic salmon smolts maintained at Port Angeles revealed no hepatocellular vacuolation. The disease recurred in smolts introduced to Site II in March 1987. In that year, samples were taken before clinical disease was apparent, and again vacuolation of the hepatocytes was the first histological change.

Though diffuse necrosis was noted in most fish in the first sample (Table 1), it became more severe in the next 2 mo (September-October 1986). Regenerative islands of hepatocytes co-occurred with these changes, and became more extensively distributed throughout the liver as the disease progressed. By 5 to 6 mo after the initial observation of the disease, the livers of most of the fish had almost completely regenerated and only occasional necrotic or vacuolated hepdiocytes were observed. However, the regenerated livers continued to show abnormalities; well-defined hepatic tubules were not apparent, and megalocytosis and melanomacrophage centers laden with ceroid were still prominent features (Fig. 9).

Megalocytosis and nuclear pleomorphism are interpreted as chronic manifestations of hepatocarcinogen toxicity, resulting in aneuploid hepatocytes as a consequence of disrupted mitosis (Wales 1967, Sinnhuber et al. 1977). Although hepatocytes with extremely enlarged nuclei are likely terminally degenerate cells, they may indicate that the liver has been exposed to a toxicant-carcinogen and could ultimately develop hepatic neoplasms if the fish were to survive. Megalocytosis (Myers et al. 1987), nuclear inclusions in hepatocytes similar to those described here (Wilson 1954), ceroid deposition in the liver (Hendricks et al. 1984), and hydropic degeneration of hepatocytes (Couch \& Courtney 1987) have all been observed in populations which ultimately developed hepatic neoplasms. However, no neoplasms or preneoplastic lesions (basophilic or eosinophilic foci) were observed in the present study. Because surviving fish which were transferred to the Battelle laboratory died after 3 mo due to bacterial infections, it was not possible to determine if they would have ultimately developed liver neoplasms.

Inflammation of the liver was characteristic of the disease. In the early samples perivascular cuffing was a prominent feature (Fig. 4), and in later samples foci of inflammation, often consisting of melano-macrophages, were prevalent. Melanization of the kidney interstitium was also consistently observed. Melanization of the kidney and formation of melano-macrophage centers in the liver may indicate exposure to anthropogenic contaminants (Wolke et al. 1985) and these changes observed in the present study may be directly related to the suspected toxicopathic liver lesions. However, increased melanin deposition in the kidney may also reflect overall poor health status of the fish and has been observed in fish stressed by starvation (Agius \& Roberts 1981), infectious diseases and advanced age (Roberts 1975).

The liver lesions were consistent with those induced by hepatic toxicants, and the lack of a demonstrable infectious agent associated with the lesions supports this conclusion. Diffuse necrosis with concurrent regenerative islands and hepatocellular pleomorphism, referred to as megalocytosis when nuclei are tremendously enlarged (Wales 1967), are consistent features in the liver of rainbow trout Salmo gairdneri fed diets containing the potent hepatocarcinogen aflatoxin. Affected trout surviving the initial toxic effects of this carcinogen exhibit a high incidence of liver neoplasia (Ashley 1967, Simon et al. 1967, Sinnhuber et al. 1977, Wales 1957, Wales et al. 1978) In addition, similar lesions were observed in channel catfish Ictalurus punctatus (Hinton et al. 1978), rainbow trout (Hacking et al. 1978) and lake trout Salvelinus namaycush (Couch 1975) exposed to polychlorinated biphenyls; in cutthroat trout Salmo clarki exposed to endrin (Eller 1971); in zebrafish Brachydanio rerio (Stanton 1965), sheepshead minnow Cyprinidon variegatus (Couch \& Courtney 1987) and Japanese medaka Oryzias latipes (Hinton et al. 1987) exposed to diethylnitrosamine; in English sole exposed parenterally to sediment extracts from a contaminated harbor in Puget Sound (M. S. Myers unpubl,; and in ruffe Gymnocephalus cernua, flounder Platichthys flesus and smelt Osmerus eperlanus from presumably polluted water (Peters et al. 1987).

It is unlikely that the liver lesions observed in the present study were induced by toxins or toxicants in the commercial diet. In 1986, histological examination. of Atlantic salmon that were fed the same diet and were maintained in seawater net pens near Port Angeles, Washington (Fig. 1) exhibited none of the liver lesions described here. Furthermore, that population was composed of the same genetic strains as those from the Port Townsend sites and was hatched and reared at the same freshwater facilities prior to seawater introduction.

We suggest that the liver lesions were likely induced by toxicants in the marine environment. A high prevalence of hepatic neoplasms and other degenerative changes have been reported in flatfishes (family Pleuronectidae) from certain polluted areas in Puget Sound (Malins et al. 1984, 1985a, b, Myers et al. 1987). Nuclear pleomorphism and megalocytosis are significantly associated with other hepatocellular necrotic changes in English sole and are viewed as the initial toxicopathic lesions resulting from exposure to toxic or carcinogenic chemicals in sediments from polluted waterways and embayments in Puget Sound (Myers et al. 1987). Furthermore, these authors also reported that 
the lesions co-occur at a statistically significant frequency with liver adenomas and preneoplastic basophilic nodules.

In contrast to studies with demersal fishes, the fish in our study were not directly in contact with sediments; we therefore presumed that the toxicant occurred within the water column. Although the fish are fed the commercial diet daily throughout the year, they also feed extensively on larval crustaceans in summer during plankton blooms and it is difficult to determine the actual contribution of naturally occurring food to the total diet. Therefore, accumulation of the toxicant through the food chain, as well as by direct contact with a water-borne contaminant, must be considered. Although the source of the suspected toxicant has not been identified, it is apparently persistent; severe hepatic necrosis has again been observed in fish introduced to Site II in April 1987. A pulp mill and a US Navy ammunition depot are located on Port Townsend Bay. Along with boat traffic and sewage discharge from waterfront communities, they are possible sources of the presumed toxicant. Several studies (Oikari \& Nakari 1982, Oikari et al. 1984, 1985, Oikari \& Nittylä 1985, Oikari \& Kunnamo-Ojala 1987) reported biochemical and physiological changes in rainbow trout exposed to pulp mill effluent in cages for several days, but these investigations did not include histological examinations or long-term exposures. These authors also detected high levels of pulp mill contaminants (resin acids and chlorinated phenolics) in the liver and bile of the exposed trout, and Krahn et al. (1986) detected high levels of aromatic hydrocarbon metabolites in flatfish with liver lesions in Puget Sound. To identify the toxicant and its source in our study, liver and bile samples for chemical analysis have been collected from affected Atlantic salmon introduced to Site II in 1987.

The study salmon held in net pens at these sites, and possibly at others, provides an excellent opportunity for the examination of hepatic and other organ-specific lesions in fish potentially exposed to anthropogenic toxicants in the environment. Unlike some studies examining wild fishes as indicators of xenobiotic exposure, as discussed by Mix (1986), the net pen situation can allow for more precise determination of the onset and sequence of pathological changes, as well as permitting more accurate and complete age, genetic and nutrition data for the species employed.

Acknowledgements. The Battelle Marine Research Laboratory is part of the Pacific Northwest Laboratory, which is operated for the US Department of Energy by Battelle Memorial Institute under Contract DE-AC06-76RLO 1830, which supported this work. This work was also supported by Battelle Memorial Institute, Corporate Technical Development Project Number B-0322-4051, Columbus, Ohio, and Sea Farm
Washington. We thank Dr R. P. Hedrick for assistance with the virological examinations, Drs J. W. Fournie, J. M. Groff, W E. Hawkins, and S. F. Wellings for helpful comments on the histological material, and C. F. Dungan, E. Chen and M. T Wilkinson for histological and electron microscopy preparations.

\section{LITERATURE CITED}

Amos, K. H. (1985). Procedures for the detection and identification of certain pathogens, 3rd edn. Fish Health Section, Am. Fish. Soc., Corvallis, Oregon

Agius, C., Roberts, R. J. (1981). Effects of starvation on the melanomacrophage centres of fish. J. Fish Biol. 19: 161-169

Ashley, L. M. (1967). Histopathology of rainbow trout aflatoxicosis. In: Halver, J. E., Mitchell, I. A. (eds.) Trout hepatoma research conference papers, research report 70. Bureau of Sport Fisheries and Wildlife, Washington, D.C., p. 103-120

Couch, J. (1975). Histopathological effects of pesticides and related chemicals on the livers of fishes. In: Ribelin, W. E. Migaki, G. (eds.) The pathology of fishes. University of Wisconsin Press, Madison, Wisconsin, p. 559-584

Couch, J. A., Courtney, L. A. (1987). N-Nitrosodiethylamineinduced hepatocarcinogenesis in the estuarine sheepshead minnow (Cyprinidon variegatus): neoplasms and related lesions with comparisons to mammalian lesions. J. natn. Cancer Inst. 79: 297-321

Eller. L. L. (1971). Histopathological lesions in cutthroat trout (Salmo clarki) exposed chronically to the insecticide endrin. Am. J. Pathol. 64: 321-336

Ferguson, H. W., Rice, D. A., Lynas, J. K. (1986). Clinical pathology of myodegeneration (pancreas disease) in Atlantic salmon (Salmo salar). Vet. Rec. 119: 297-299

Hacking, M. A., Budd, J., Hodson, K. (1978). The ultrastructure of the liver of the rainbow trout: normal and modification after chronic administration of a polychlorinated biphenyl Aroclor 1254. Can. J. Zool. 56: 477-491

Harrell, L. W., Elston, R. A., Scott, T., Wilkinson, M. T. (1986). A significant new systemic disease of net-pen reared chinook salmon (Oncorhynchus tshawytscha) brood stock. Aquaculture 55: 249-262

Hendricks, J. D., Meyers, T. R., Shelton, D. W. (1984). Histological progression of hepatic neoplasia in rainbow trout (Salmo gairdneri). In: Hoover, K. L. (ed.) Use of small fish species in carcinogenicity testing. Nat. Cancer Inst. Monograph 65, U.S. Government Printing Office, Washington, D.C., p. $321-336$

Hinton, D. E., Couch, J. A., Teh, S. J., Courtney, L. A. (1988). Cytological changes during progression of neoplasia in selected fish species. Aquat. Toxicol. 11: 77-112

Hinton, D. E., Klaunig, J. E., Lipsky, M. M. (1978). PCBinduced alterations in teleost liver: a model for environmental disease in fish. Mar. Fish. Rev. 40: 47-50

Humason, G. L. (1979). Animal tissue techniques. W. H. Freeman Co., San Francisco

Kent, M. L., Elston, R. A. (1987). Pancreas disease in penreared Atlantic salmon in North America. Bull. Eur. Ass. Fish. Path. 7: 29-31

Krahn, M. M., Rhodes, L. D., Myers, M. S., Moore, L. K., MacLeod, Jr., W. D., Malins, D. C. (1986). Associations between metabolites of aromatic compounds in bile and the occurrence of hepatic lesions in English sole (Parophrys vetulus) from Puget Sound, Washington. Archs. environ. Contam. Toxicol. 15: 61-67

Luna, L. G. (1968). Armed Forces Institute of Pathology manual of histological staining. McGraw-Hill, New York 
Malins, D. C., Krahn, M. M., Myers, M. S., Rhodes, L. D., Brown, D. W., Krone, C. A., McCain, B. B., Chan, S. L. (1985a). Toxic chemicals in sediments and biota from a creosote-polluted harbor: relationships with hepatic neoplasms and other hepatic lesions in English sole (Parophrys vetulus). Carcinogenesis 10: 1463-1469

Malins, D. C., Krahn, M. M., Brown, D. W., Rhodes, L. D., Myers, M. S., McCain, B. B., Chan, S. L. (1985b). Toxic chemicals in marine sediment and biota from Mukilteo, Washington: relationships with hepatic neoplasms and other hepatic lesions in English sole (Parophrys vetulus). J. natn. Cancer Inst. 74: 487-494

Malins, D. C., McCain, B. B., Brown, D. W., Chan, S. L., Myers, M. S., Landahl, J. T., Prohaska, P. G., Freidman, A. J., Rhodes, L. D., Burrows, D., G., Gronlund, W. D., Hodgins, H. O. (1984). Chemical pollutants in sediments and diseases of bottom-dwelling fish in Puget Sound, Washington. Environ. Sci. Technol. 18: 705-713

Mix, M. C. (1986). Cancerous diseases in aqulatic animals and their association with environmental pollutants: a critical literature review. Mar. environ. Res. 20: 1-141

Munro, A. L. S., Ellis, A. E., McVicar, A. H., McLay, H. A., Needham, E. A. (1984). An exocrine pancreas disease of farmed Atlantic salmon in Scotland. Helgoländer Meeresunters. 37: 571-586

Myers, M. S., Rhodes, L. D., McCain, B. B. (1987). Pathologic anatomy and patterns of occurrence of hepatic neoplasms, putative preneoplastic lesions, and other idiopathic hepatic conditions in English sole (Parophrys vetulus) from Puget Sound, Washington. J. natn. Cancer Inst. 78: 333-363

Oikari, A., Holmbom, B., Ånäs, E., Miilunpalo, M., Kruzynski, G., Castrén, M. (1985). Ecotoxicological aspects of pulp and paper mill effluents discharged to an inland water system: distribution in water, and toxicant residues and physiological effects in caged fish (Salmo gairdneri). Aquat. Toxicol. 6: 219-239

Oikari, A., Kunnamo-Ojala, T (1987). Tracing of xenobiotic contamination in water with the aid of fish bile metabolites: a field study with caged rainbow trout (Salmo gairdneri). Aquat. Toxicol. 9: 327-341

Oikari, A. O. J., Nakari, T (1982). Kraft pulp mill effluent components cause liver dysfunction in trout. Bull. environ. Contam. Toxicol. 28: 266-270
Oikari, A., Nakari, T., Holmbom, B. (1984). Sublethal actions of simulated kraft pulp mill effluents (KME) in Salmo gairdneri: residues of toxicants, and effects on blood and liver. Annls. Zool. fenn. 21: 45-53

Oikari, A. O. J., Nittylä, J. (1985). Subacute physiological effects of bleached kraft mill effluent (BKME) on the liver of trout, Salmo gairdneri. Ecotoxicol environ. Saf. 10: $159-172$

Peters, N., Köhler, A., Kranz, H. (1987). Liver pathology in fishes from the Lower Elbe as a consequence of pollution. Dis. aquat. Org. 2: 87-97

Roberts, R. J. (1975). Melanin-containing cells of teleost fish and their relation to disease. In: Ribelin, W. E., Migaki, G. (eds.) The pathology of fishes. University of Wisconsin Press, Madison, Wisconsin, p. 399-428

Simon, R. C., Dollar, A. M., Smuckler, E. A. (1967). Descriptive classification on normal and altered histology of trout. In: Halver, J. E., Mitchell, I. A. (eds.) Trout hepatoma research conference papers, research report 70. Bureau of Sport Fisheries and Wildlife, Washington, D.C., p. 18-28

Sinnhuber, R. O., Hendricks, J. D., Wales, J. H., Putnam, G. B. (1977). Neoplasms in rainbow trout, a sensitive animal model for environmental carcinogenesis. Ann. N. Y Acad. Sci. 298: $389-408$

Stanton, M. F. (1965). Diethylnitrosamine-induced hepatic degeneration and neoplasia in the aquarium fish, Brachydanio rerio. J. natn. Cancer Inst. 34: 117-134

Wales, J. H. (1967). Degeneration and regeneration of liver parenchyma accompanying hepatomagenesis. In: Halver, J. E., Mitchell, I. A. (eds.) Trout hepatoma research conference papers, research report 70. Bureau of Sport Fisheries and Wildlife, Washington, D.C., p. 56-59

Wales, J. H., Sinnhuber, R. O., Hendricks, J. D., Nixon, J. E., Eisele, T. A. (1978). Aflatoxin $B_{1}$ induction of hepatocellular carcinoma in the embryos of rainbow trout (Salmo gairdneri). J. natn. Cancer Inst. 60: 1133-1139

Wilson, J. W. (1954). Hepatomas produced in mice by feeding bentonite in the diet. Ann. N. Y. Acad. Sci, 57: 678-687

Wolke, R. E., George, C. J., Blazer, V. S. (1985). Pigmented macrophage accumulations (MMC; $\mathrm{PMB}$ ): possible montiors of fish health. In: Hargis, W. J. (ed.) Parasitology and pathology of marine organisms of the world oceans, NOAA Tech. Rep. NMFS 25. Nat. Tech. Info. Serv, Springfield, Virginia, p. 93-97 